Kováts Gergely

\title{
A TERMELŐSZÖVETKEZETTŐL AZ UDVARI BOLONDIG - AZ EGYETEM TÁRSADALMI SZEREPEI A 21. SZÁZADBAN ${ }^{1}$
}

From the Producers' Cooperative to the Court Fool - The Social Roles of the University in the $21^{\text {st }}$ Century

Dr. Kováts Gergely, egyetemi docens, Budapesti Corvinus Egyetem, Vezetéstudományi Intézet, igazgató, Budapesti Corvinus Egyetem, Nemzetközi Felsőoktatási Kutatások Központja, gergely.kovats@uni-corvinus.hu

Noha széles körü egyetértés van arról, hogy az egyetemek a társadalomban fontos szerepet töltenek be, arról már megoszlanak a vélemények, hogy pontosan miben is áll ez a szerep. Az elvárások nagyon sokrétüek és ellentmondásosak. A tanulmányban arra a kérdésre keresem a választ, hogyan lehetne rendszerezni az egyetem társadalmi szerepeit, és ez nyújt-e támpontokat a 21. századi egyetemmel szembeni kihívásokhoz (tudásmonopólium elveszítése, nemzetállamok gyengülése, a tudás relativizálódása). A javasolt keretrendszer két szempont mentén fogalmazza meg az egyetem társadalmi szerepeit: egyrészt a termelés jellege (termék/folyamat), másrészt a társadalmi, gazdasági és politikai berendezkedéshez füzödö viszony alapján (konszenzus/disszenzus). Ebböl kiindulva négy társadalmiszerep-modellt mutatok be: a termelöszövetkezetet, a katalizátort, a világítótornyot és a görbe tükröt. A tanulmány végén a nézetek integrálhatóságát vizsgálom meg.

KulcsszavaK:

felsőoktatás, társadalmi szerep, az egyetem haszna, egyetem, küldetés

A tanulmány az FK 138875 számú, „Modellváltás a felsőoktatásban - Hogyan befolyásolja az intézményi kormányzás átalakulása a magyar egyetemeket?” című OTKA projekt keretében készült. 
Although there is a broad consensus that universities play an important role in society, opinions are already divided on exactly what this role is. The expectations are very diverse and contradictory. In this study, I seek the answer to the question of how the social roles of the university could be systematised and whether this provides clues to the challenges the university of the $21^{\text {st }}$ century faces (loss of knowledge monopoly, weakening of nation states, relativisation of knowledge). The proposed framework describes the social roles of the university according to two dimensions: on the one hand, on the basis of the nature of production (product/process), and on the other hand, on the basis of the relation to the social, economic and political system (consensus/dissensus). Based on this, I present four social role models: the producers' cooperative, the catalyst, the light tower and the distorting mirror. At the end of the study, I examine the integrability of views.

KeYwords:

university, higher education, social roles, Uses of University, mission 


\section{BEVEZETÉS}

A felsőoktatással foglalkozó szereplők körében döntően egyetértés van arról, hogy a felsőoktatás fontos szerepet tölt be a társadalmi intézményrendszerben, fontos társadalmi küldetése van. A Magna Charta Universitatum (1988) például úgy fogalmaz, hogy „az ismeretek fiatalok közötti terjesztésén keresztül az egyetemeknek ma már a társadalom egészét kell szolgálniuk" (kiemelés a szerzőtől). ${ }^{2}$

Arról azonban már többnyire megoszlanak a vélemények, hogy a társadalmi szerep csak egy az intézményi missziók között (lásd az oktatás és kutatás melletti „harmadik misszió”), vagy a társadalom szolgálatának az egyetem minden tevékenységét át kell hatnia. ${ }^{3}$

Míg az elöbbi értelmezés inkább arra fókuszál, hogy az egyetem milyen közvetlen hasznokat termel a közvetlen környezetének (például milyen szolgáltatásokat nyújt), addig az utóbbi értelmezés abból indul ki, hogy a felsőoktatás minden tevékenysége valamilyen társadalmi igényre reflektál, valamilyen társadalmi funkciót tölt be. Ezért nehezen is választható el a felsőoktatás céljairól, hasznairól és társadalmi szerepeiről való diskurzus. Még a látszólag öncélúan, elefántcsonttoronyként működő egyetem vagy a hallgatók egyéni boldogulását támogató egyetem esetében is találhatunk olyan indokot, hogy ez végső soron miért is szolgálhatja a társadalom érdekeit (például az igazság keresése idővel társadalmilag is hasznos felfedezések alapjául szolgál, a sikeres hallgatók előbbre viszik a társadalmat), legfeljebb ez a működési mód nem elég célirányos, nem elég hatékony. E cikkben a felsőoktatás társadalmi szerepének fogalmát ebben a tágabb értelemben használom: azt értem alatta, hogy mi az a társadalomban jelentkező átfogó cél vagy igény, amelyet az egyetem müködésével igyekszik kielégíteni.

Ezt a kérdést azért érdemes vizsgálni, mert vita van arról (is), hogy pontosan mi is az a bizonyos társadalmi szerep, mi a felsőoktatás társadalmi feladata. Különösen fontos kérdés ez a közpolitika alakítói számára, akiknek választ kell adniuk arra, hogy mi indokolja a felsőoktatás egyre növekvő állami támogatását. Milyen (köz)feladatok ellátása várható el a felsőoktatástól? A különböző policy dokumentumokban explicit vagy implicit módon jelennek meg a felsőoktatás szerepével kapcsolatos nézetek.

Az Európa Tanács miniszteri bizottsága által kiadott ajánlás összetett célrendszert fogalmaz meg. Az egyetemek

„megfeleljenek a társadalom sokszínű elvárásainak, és teljesítsék különböző és egyformán fontos célkitüzéseiket, többek között: a fenntartható foglalkoztatásra való felkészítést; felkészítést az aktív állampolgári életre a demokratikus társadalmakban;

Magna Charta Universitatum (1988): www.felvi.hu/felsooktatasimuhely/archivum/kulfold/magna_charta_ universitatum

3 Isabel Menezes - Márcia Coelho - Jose P. Amorim: Social and Public Responsibility, Universities. In P. Teixeira J. Shin (szerk.): Encyclopedia of International Higher Education Systems and Institutions. Dordrecht, Springer, 2020. 2540-2545. 
személyes fejlődést; széles, fejlett tudásbázis fejlesztését és fenntartását tanítás, tanulás és kutatás révén". ${ }^{4}$

Az Európai Bizottság felsőoktatásról szóló tájékoztató oldala elsősorban a felsőoktatás gazdasági szerepét hangsúlyozza, amikor azt írja, hogy „a felsőoktatás és annak kapcsolatai a kutatással és innovációval kulcsfontosságú szerepet játszanak az egyéni és társadalmi fejlődésben, valamint a magasan képzett humán tőke és az elkötelezett polgárok biztosításában, amelyekre Európának szüksége van a munkahelyek, a gazdasági növekedés és a jólét megteremtéséhez" ${ }^{5}$

Az UNESCO 2009-es kommünikéje pedig kijelenti, hogy

„a felsőoktatási intézményeknek [...] az alapvető funkcióik (kutatás, oktatás és a közösség szolgálata) révén fokozniuk kell interdiszciplináris fókuszukat, és elő kell mozdítaniuk a kritikus gondolkodást és az aktív állampolgárságot. Ez hozzájárulna a fenntartható fejlődéshez, a békéhez, a jóléthez és az emberi jogok megvalósításához, beleértve a nemek közötti egyenlöséget."6

A magyar policy dokumentumokban is tetten érhetőek a felsőoktatással kapcsolatos társadalmi várakozások. A Fokozatváltás a felsőoktatásban címü stratégia például hangsúlyozza, hogy a felsőoktatásnak „meghatározó gazdasági szerepe van”, 7 ugyanakkor azt is hozzáteszi, hogy „komplex küldetésének teljesítésével a felsőoktatás sokféle módon szolgálja a közösséget, azonban még oly fontos funkciói közül is kiemelendő a társadalmi mobilitás elösegítése", azaz van egyfajta esélykiegyenlítő szerepe is. Egy korábbi dokumentum, a Széll Kálmán-terv még markánsabban helyezi a munkaerőpiac és a gazdaság kiszolgálását a középpontba, amikor úgy fogalmaz, hogy

„akár a magyar szakképzést, akár a felsőoktatást tekintjük, jól látszik, hogy az oktatási rendszer egésze milyen távol esik a gazdaság és a munkaerőpiac tényleges igényeitől. [...] A magasabb színvonalon képzett diák - akármelyik szintjén az oktatási rendszernek - magasabb hozzáadott értékü munka elvégzésére lesz alkalmas. Munkája tehát önmaga és a közösség számára is nagyobb értéket teremt, nagyobb mértékben járul hozzá a gazdaság növekedéséhez, az államadósság újratermelésének megakadályozásához" ${ }^{8}$

4 Council of Europe: Recommendation of the Committee of Ministers to member states on the public responsibility for higher education and research $\mathrm{CM} / \operatorname{Rec}(2007) 6$ (2007. május 16.).

Lásd: https://ec.europa.eu/education/policies/higher-education/about-higher-education-policy_en

UNESCO: World Conference on Higher Education 2009. Final report. Paris, UNESCO. (2009). 2.

EMMI: Fokozatváltás a felsőoktatásban. Budapest, Emberi Erőforrások Minisztériuma, 2015. 10. (kiemelés az eredetiben).

$8 \quad$ Magyarország Kormánya: Széll Kálmán terv összefogás az adósság ellen (2011). 22-24. 
A csak példaszerűen kiválasztott néhány dokumentum alapján is látható az elvárások számossága. A felsőoktatási intézményekkel szembeni társadalmi elvárások között a tudás „termelése” és a szakképzett munkaerő biztosítása, továbbá az ennek révén bekövetkező innováció, gazdasági fejlődés és jóllét mellett gyakran jelenik meg az egyéni kiteljesedés támogatása, a társadalmi egyenlőtlenségek mérséklése, a városok, régiók fejlesztésének igénye és a demokratikus elköteleződés erősítése is.

A felsőoktatással szembeni társadalmi elvárások számossága feszültséget eredményez. A célok és elvárások között prioritási sorrendet kell felállítani, mert az erőforrások korlátosak. Ráadásul az elvárások gyakran ellentmondanak egymásnak. Például a munkaerőpiac gyakorlatias igényeinek kiszolgálása nem mindig illeszkedik az egyén saját fejlődési igényeihez, az aktív állampolgári létre való felkészítéshez vagy demokratikus értékeket valló, kritikus értelmiségképző szerephez. Ezekből adódóan a felsőoktatás szerepével kapcsolatos viták részben értékválasztási és hatalmi viták is.

A feszültségek feloldásának egyik módja, hogy egyre komplexebb felsőoktatási rendszereket és/vagy intézményeket hozunk létre, ami a felsőoktatás homogenizálódásával és differenciálódásával kapcsolatos kérdéseket vet fel. ${ }^{9}$ Egyes országokban komplex intézményeket hoznak létre összetett célokkal, más országokban különböző intézménytípusokat alakítanak ki a különböző célok szolgálatára. Mindkét megoldás irányítási és finanszírozási nehézségekhez vezet, csak a felsőoktatási rendszer különböző szintjein. A komplexitásból eredő nehézségeket - a jó kormányzás mellett - világosabb prioritások kijelölésével és/vagy a társadalmi elvárások mérséklésével is lehet kezelni, ez viszont épp az értékválasztási vitákat erősíti fel.

A folyamatot nehezíti az is, hogy hiányzik egy olyan rendszerezés, amely iránytűként szolgálhat a társadalmi elvárások sokaságában. E cikkben pontosan ennek a hiánynak egy lehetséges pótlására teszek kísérletet. Az elvárásokat ugyanis jellemzően ad hocnak tünő felsorolásokban, kategorikus kijelentésekben találhatjuk meg, ám hiányzik valamilyen mögöttes rendezőelv, amely az elvárásoknak keretet adna. Kutatási kérdésem tehát az, hogy milyen módon lehetne rendszerezni a felsőoktatás társadalmi feladatait, szerepeit? Tudunk-e olyan rendszerező elveket meghatározni, amelyek mentén a felsőoktatási intézményekkel szembeni elvárások modellezhetők? Úgy vélem, hogy egy ilyen rendszerezés hasznos segítség lenne a felsőoktatásról szóló társadalmi viták kapcsán is.

A cikk két nagy részből áll: először röviden bemutatom a felsőoktatási rendszerek fejlödését és az egyes rendszerek mélyén megbúvó társadalmi szerepelvárásokat is. Ezt követően egy rendszerezést mutatok be, amely két dimenzió - a társadalmi konszenzus/disszenzus támogatása, illetve az eredmény és folyamat fókusz - mentén ragadja meg a felsőoktatás társadalmi szerepeit, és ezeket egy-egy modellbe (metaforába) süríti. A cikk végén olyan integráló szerepértelmezéseket mutatok be, amelyek magyarázatul szolgálnak arra, hogy az egyetemek a modern társadalmakban miért töltenek be sajátosan ellentmondásos helyzetet.

Hrubos Ildikó: Differenciálódás, diverzifikálódás és homogenizálódás a felsőoktatásban. Educatio, 11. (2002), 1-4. 96-106. 


\section{A FELSŐOKTATÁS TÁRSADALMI SZEREPEINEK TÖRTÉNETI ALAKULÁSA}

A felsőoktatás funkcióival, társadalmi szerepével kapcsolatos vita nem új keletű. Igen régre nyúlik vissza, hiszen a felsőoktatás mindig valamilyen társadalmi igényre reflektálva müködött. A középkori egyetem például írástudók képzőhelyeként, egyfajta szakképzésként értelmezhető. Ennél differenciáltabb felfogás a nemzeti egyetemek 18. századi kialakulásával jelent meg, amikor Európa sok országában kezdődött meg a felsőoktatás központosított újra- vagy átszervezése, és az átszervezés alapjául más-más eszme szolgált. Nem meglepő ezért, hogy a filozófában ettől a korszaktól kezdve jelennek meg rendszeresen az egyetemek céljával, hasznával és társadalmi szerepével kapcsolatos írások. ${ }^{10}$ Hadd mutassam be röviden a nemzetállamok hajnalán kibontakozó modelleket. ${ }^{11}$

Az angol (oxbridge-i egyetemekre épülö) modell középpontjában a személyiségfejlesztés, a nevelés áll, és ezen keresztül a társadalmi elit reprodukciójának biztosítása. A cél az elit homogén társadalmi kultúrájának és a kapcsolatrendszerének kialakítása a gentlemenek közös, college rendszerü, tutori képzése révén.

A francia (napóleoni) modell középpontjában a szakképzés áll. A cél, hogy olyan hallgatókat képezzenek, akik az állam vagy a társadalom számára fontos feladatokat tudnak ellátni. Például hadmérnökök, bányamérnökök, tanárok vagy államigazgatási szakemberek. A holisztikus képzés helyett a specializálódás válik fontos szervezőelvvé. További fontos szempont volt, hogy a képzés nem áshatja alá az állam szerepét, emiatt a kutatás sem a felsőoktatásban teljesedett ki, hanem önálló kutatóintézeti hálózatban. A későbbiekben a szovjet rendszerü felsőoktatás mutatott a franciához hasonló jegyeket (erősen specializált intézményhálózat, a tudományos akadémiákban elkülönülő kutatóhálózat).

A német (humboldti) modell a kutatást és a tudósok képzését helyezte előtérbe az oktatás és kutatás egysége révén. Ez azonban nem öncélú folyamat volt. A kutatásoknak - közvetve vagy közvetlenül - vagy a nemzeti identitás megerősítését (bölcsész- és társadalomtudományok), vagy pedig a technológiai fejlödést (természettudományok) kellett szolgálniuk. Bár az állam a tudományos kérdésekben szabad kezet ad az intézményeknek, és védelmet nyújt a piaccal szemben, a napóleoni modellhez hasonlóan itt is fontos elvárás volt, hogy a felsőoktatás a fennálló államrendet nem gyengítheti. (Ennek drámai következménye volt, ahogyan a felsőoktatás kiszolgálta a náci rezsimet.)

$\mathrm{Az}$ amerikai felsőoktatás kezdetben főként az angol modell elveit vette át, amelyet később a német modell elemeivel és kutatási fókuszaival elegyített, és ezt tökéletesítette

${ }^{10} \quad$ Részletes áttekintést lásd Ronald Barnett: The Idea of the University: Renewing the Great Tradition. In Pedro Nuno Teixeira - Jung-Cheol Shin (szerk.): The International Encyclopedia of Higher Education Systems and Institutions. Dordrecht, Springer, 2020. 2642-2648.

11 Részletesen lásd Kováts Gergely: Az egyetemek fejlődéstörténete - és ennek tanulságai. In Hrubos Ildikó - Luda Szilvia - Török Imre (szerk.): Intézményi menedzsment a felsőoktatásban 3. Budapest, FGSZE, 2013. 45-68., illetve Pavel Zgaga: Higher Education and Citizenship: 'The Full Range of Purposes.' European Educational Research Journal, 8, (2009), 2. 175-188. 
tovább (például a graduate school-ok létrehozásával). Az amerikai oktatási rendszer egyik történeti sajátossága, hogy - szemben az európaival - alulról építkezve épült ki a helyi igények szem előtt tartásával. Ez az egyetemekre is igaz volt, amelynek irányításában (például boardjaiban) kezdettől fogva erős szerepet játszottak a helyi közösség igényeit megjelenítő (laikus) szereplők. Ennek következtében az amerikai felsőoktatást erősen áthatja a gyakorlatiasság és az elkötelezett állampolgári öntudat mind az oktatás, mind a kutatás területén. ${ }^{12}$

A 20. század második felétől kezdődően a globalizálódás, a felsőoktatási rendszerek közötti verseny és mobilitás felerősítette a közöttük lévő konvergenciát. A Bolognafolyamat ennek szép példája. A rendszeres miniszteri találkozók után kiadott kommünikékben például jól tükröződnek a múltat idéző, de egyre összetettebbé váló társadalmi elvárások. A londoni kommüniké (2007) a felsőoktatás céljait a következőkben jelöli ki:

- „1) A hallgatók életre való felkészítése, hogy aktív állampolgárok legyenek egy demokratikus társadalomban,

- 2) a hallgatók felkészítése a jövőbeli karrierjükre és a személyes fejlödésük lehetővé tétele,

- 3) széles és haladó tudásbázis teremtése és fenntartása, a kutatás és innováció stimulálása.”

Ahogy arra Zgaga is rámutat, a történelmi modellek örökségét vehetjük észre ezekben a célokban: míg az első célban leginkább az amerikai felsőoktatás szemlélete tükröződik vissza, addig a másodikban a napóleoni, illetve az angol. A harmadik célban pedig a humboldti modellt érhetjük tetten.

Martin és Etzkowitz egy másféle fejlődési ívet rajzol fel. Az ő értelmezésükben a felsőoktatás két „akadémiai forradalmon” ment keresztül, aminek eredményeképpen az egyetem funkciói bővültek. Az oktatási funkció előbb a kutatással egészült ki a 19. században, majd a szolgáltatással (harmadik misszióval) bővült tovább a 20. században. Ezzel együtt viszont változott a társadalmi szerződés is: „a felülvizsgált társadalmi szerződés szerint egyértelmü elvárás, hogy a közpénzekért cserébe a tudósoknak és az egyetemeknek foglalkozniuk kell a gazdaság és a társadalom »felhasználói« igényeivel." ${ }^{13}$ Azaz az egyetemeknek ki kell lépniük az elefántcsonttoronyból, és közvetlenül is foglalkozniuk kell a társadalmi igényekkel, vagy ahogy Etzkowitz más írásaiban fogalmazott, termelőerővé kell válniuk, közvetlenül is részt kell venniük a tőketermelési folyamatokban, vállalkozniuk kell. Ez azonban Martin és Etzkowitz szerint valójában csak visszatérés ahhoz a 20. század előtti társadalmi szerződéshez, „amelyet a XIX. században a müszaki egyetemek és az Egyesült Államok land grant egyetemei testesítettek meg" ${ }^{14}$

\footnotetext{
Zgaga (2009): i. m.

Ben R. Martin - Henry Etzkowitz: The Origin and Evolution of the University Species. Journal for Science and Technology Studies (VEST), (2001), 13. 15.

14 Martin-Etzkowitz (2001): i. m. 25.
} 
Mind a felsőoktatási rendszerek konvergenciájából kiinduló érvelés, mind Etzkowitzék akadémiai forradalmai azt mutatják, hogy a felsőoktatás társadalmi szerepe egyre összetettebb. Az intézményekre (vagy a rendszer egészére) egyre újabb és újabb elvárások rakódnak, miközben a régiek is fennmaradnak és differenciálódnak. A képzés magában foglalja az elit képzését, a munkaerőpiacon helytállni képes szakemberek képzését, a kutatói utánpótlás képzését, de esetenként a felzárkóztatást is. A kutatás pedig egyszerre irányul az alapkutatásra és a jól hasznosítható alkalmazott kutatásra. A harmadik misszió és/vagy a szolgáltatási funkció pedig magában foglalja a területfejlesztést, a gazdasági növekedés elősegítését, az innovációs rendszerben való szerepvállalást, a közösségek revitalizálását (community engagement), vagy éppen a tőketermelésbe való közvetlen bekapcsolódást (capital production). Még ha egy intézménynek nem is kell minden elvárást teljesítenie, akkor is egyre több szerepben kell megjelennie. Emiatt Burton Clark egyenesen „demand overload-ról”, keresleti túlterhelésről beszél. „Az egyetemek az elvárások kereszttüzébe kerülnek. És mindegyik keresleti csatorna nagy sebességgel változik."15

$\mathrm{Az}$ elmúlt három-négy évtizedben újabb kihívások jelentek meg, amelyek hatással vannak az egyetem társadalmi szerepéről való gondolkodásra is.

- Az egyik a felsőoktatás oktatási és kutatási monopóliumának megszűnése. A felsőoktatási intézmények a felvilágosodást követő időszakban a tudás meghatározásának, termelésének és elosztásának központi intézményei voltak (van, ahol az akadémiákkal, kutatóintézetekkel együtt). A felsőoktatás expanziójának hatására azonban ez a központi szerep erodálódott. Az oktatás és kutatás iránti növekvő keresletet sokféle új, magasan specializált szervezet elégíti ki: vállalati egyetemek, think tank-ek, tanácsadó cégek és a vállalatok K+F-területei. Ez, valamint a tudás hozzáférhetőségének egyszerüsödése (például Wikipedia, fél-legális tudásmegosztó oldalak) felerősítették az egyetemek társadalmi szerepével kapcsolatos diskurzust is.

- A második a nemzetállamok szerepének változása a globalizáció és a transznacionális vállalatok növekedésének fényében. A ma leginkább elterjedt egyetemi archetípusok szorosan kötődnek a nemzetállamokhoz: nemcsak a szabályozási és a finanszírozási függés miatt, hanem ideológiájukban is. Az oktatás és kutatás működése gyakran a nemzetállami kultúra reprodukálására irányult, és a nemzetállam szerepének, legitimációjának erősítését szolgálta. Ha azonban a nemzetállamok szerepe megkérdőjeleződik, és megjelennek alternatív szerveződési logikák is, az megnyitja az egyetemek szerepéről szóló diskurzust is, egyfajta „ontológiai válságot” eredményezve. Hogyan értelmezzük például egy olyan, több országban müködő, nemzetközi egyetem társadalmi szerepét, amely döntően saját forrásokból működik? ${ }^{16}$

- Végül érdemes megemlíteni a posztmodernizmust is, amely szintén hatással van az egyetemek társadalmi szerepével kapcsolatos diskurzusra. A 20. századi egyetemek

15 Burton R. Clark: Creating Entrepreneurial Universities. Organizational Pathways of Transformation. London, IAU Press \& Emerald, 1998. 131.

16 Lásd még például Bill Readings könyvét: Bill Readings: The University in Ruins. Cambridge (Ma.) and London, Harvard University Press, 1996. 
a felvilágosodás korának és értékeinek termékei. A posztmodern éppen ennek relativizmusára mutat rá. Ezzel azonban elvész az az archimédeszi pont, amelyhez mindenki igazodni tud, és amelyből az egyetem az autoritását meríti. „Episztemológiai válság” lép fel, amelyben csak szubjektív nézőpontok és önkényes „nagy narratívák” vannak. És vajon mi lehet az egyetemek szerepe egy olyan világban, amelyet tények helyett narratívák uralnak, és ahol nincs fix vonatkoztatási keretrendszer, mert maga a vonatkoztatási keretrendszer is vita tárgya? Ha a világunk nem egyszerüen komplex, hanem „szuperkomplex"? ${ }^{17}$

Az e dilemmákra adható egyik kézenfekvő válasz az egyetemek piacosítása. Végső soron az oktatási és kutatási szolgáltatás nem különbözik más szolgáltatásoktól. Az egyetemek társadalmi szerepe az irántuk való kereslettel mérhető meg. De vajon nem veszítjük-e el az egyetemek lényegét, ha egyszerü üzleti vállalkozásként kezeljük őket? Lehet-e más társadalmi szerepet osztani rájuk egy radikálisan változó közegben? E kérdés megválaszolásához érdemes az egyetemek társadalmi szerepével kapcsolatban más szempontokat is figyelembe venni. Ehhez az egyetemek társadalmi szerepének olyan rendszerezését szeretném bemutatni, amely segít minket az egyetem feladatairól való gondolkodásban.

\section{AZ EGYETEMEK TÁRSADALMI SZEREPÉNEK RENDSZEREZÉSE}

A rendszerező modellben két szempont mentén vizsgálom az egyetemek társadalmi szerepét.

A vízszintes tengely azt mutatja meg, hogy az egyetemektől milyen típusú eredményeket várunk el. Azt szeretnénk, hogy valamilyen kézzelfogható, önálló outputot állítsanak elö, amelyet mások fel tudnak használni (eredményfókusz), vagy pedig azt szeretnénk, hogy az egyetem más szereplők müködési folyamatát alakítsa, befolyásolja (folyamatfókusz). Másként megfogalmazva: az egyetemek sikerességét a „termelési” tevékenységük mennyiségi és minőségi eredményessége alapján ragadjuk meg, vagy inkább abban, hogy menynyire képesek mások működését támogatni, katalizálni?

A függőleges tengely azt mutatja, hogy az egyetemeknek inkább stabilizációs vagy inkább megújulási szerepet tulajdonítunk. Az egyetemektől várhatjuk azt, hogy az uralkodó intézményeket és működési mechanizmusokat (a konszenzust) erősítsék, vagy pedig azt, hogy ezek alternatíváit legyenek képesek megfogalmazni és népszerüsíteni (disszenzus)? Egy társadalomban mindkettő szerepe fontos. Az egyetem a tekintélyével hozzá tud járulni ahhoz, hogy a fennálló társadalmi-gazdasági-politikai berendezkedés legitimitása, stabilitása erősödjön. Az egyetem ez esetben olyan változásokat segít elő, amelyek a berendezkedés alapjait nem érintik, azokon belül valósul meg, így a változásoknak vannak korlátai. Ahogy láttuk, a 19. és 20. századi nemzeti egyetemektől például alapvetően

17 Ronald Barnett: University knowledge in an age of supercomplexity. Higher Education, 40. (2000), 409-422. 
a nemzetállamok megerősítését, legitimálását várták el. Ugyanakkor ahhoz is füződhet erős közösségi érdek, hogy a társadalom képes legyen alkalmazkodni a technológiai-környezeti feltételek változásához akár a társadalmi, gazdasági, politikai berendezkedés radikális felülvizsgálatával is. A változáshoz álljanak rendelkezésre alternatív forgatókönyvek, olyan szellemi kapacitás és gondolkodói kör, amely már az új idők szeleinek megfelelően értelmezi a világot. Az egyetemek ennek bölcsői, éltetői vagy akár motorjai is lehetnek. Így tehát az egyetemeknek éppúgy feladatuk lehet „rendszerkatonák” képzése, mint „forradalmároké” - még akkor is, ha ez utóbbi nincs mindig ínyére a mindenkori gazdasági, politikai elitnek.

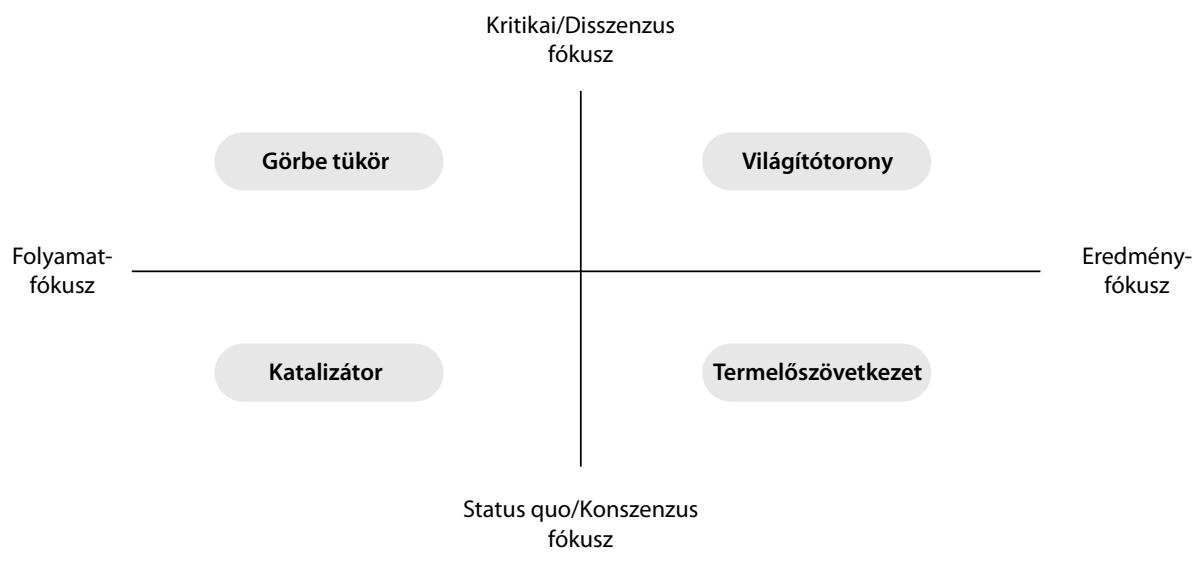

1. ábra • Az egyetem társadalmi szerepeinek rendszerezése és modelljei (Forrás: a szerző szerkesztése)

Ha a fenti két szempontot nézzük, akkor abból négy társadalmi-egyetemi együttműködési elvárásrendszer (modell) rajzolódik ki. Ezeket egy-egy metaforával szemléltetem: ez a termelöszövetkezet, a katalizátor, a világítótorony és a görbe tükör.

Az egyes modellekben az egyetemek nem abban különböznek egymástól, hogy más az alapvető tevékenységük, mondjuk az egyikben az egyetem elsősorban oktatást végez, a másikban pedig kutatást. Akármelyik modell szerint is képzeljük el a 21. századi egyetemet, az egyetem mindegyikben foglalkozik oktatással, kutatással és harmadik missziós tevékenységgel, de ezek célja, irányultsága és tartalma lesz más, ami az egyetem alapvető társadalmi szerepéről alkotott felfogás különbségéből ered. Ez persze kihat a fontosabb érintettek, például az oktatók, hallgatók és kutatók szerepének (ön)értelmezésére is.

\subsection{Az egyetem mint termelöszövetkezet}

Az egyetem mint termelöszövetkezet azt hangsúlyozza, hogy az egyetem fö feladata az uralkodó intézményrendszert támogató erőforrások előállítása, „termelése”. 
Az oktatás és nevelés területén ez magában foglalhatja például egy rendszerkonform elit kitermelését, vagy az adott gazdasági feltételrendszerben hatékonyan dolgozó, szakképzett munkaerő kiképzését.

A kutatás célja olyan ismeretek (műszaki- és szociáltechnológiák) előállítása, amelyek erősítik a fennálló rendszer stabilitását. Ebbe beletartoznak a fennálló társadalmi-politikai berendezkedést erősítő kulturális javak, eszmék előállítása is. De idesorolható azoknak a technológiáknak a fejlesztése is, amelyek növelik a különböző társadalmi és gazdasági folyamatok feletti kontrollt, vagy hatékonyabbá teszik a rendszer legitimitása szempontjából fontos erőforrások előállítását (azaz növelik a termelékenységet). A kutatás révén tehetünk szert mondjuk a szervezeti vagy társadalmi folyamatok irányítását, kézben tartását elősegítő ismeretekre (például társadalomtudományok), vagy olyan műszaki technológiákra, amelyek növelik a gazdasági termelékenységet, jóllétet (amely például különösen fontos egy kapitalista társadalomban).

A termelőszövetkezetként értelmezett egyetem harmadik missziós tevékenysége keretében elsősorban olyan szolgáltatásokat nyújt, amelyek növelik a termelékenységet, a gazdasági növekedést. Például bérkutatást végez vagy technológiai transzferszolgáltatást nyújt az egyetem, vagy maga is vállalkozni kezd, szakértelmét piacosítja és közvetlenül is bekapcsolódik a tőketermelésbe (például spin-off cégeket hoz létre).

Ehhez a metaforához jól illeszkednek a korábban azonosított napóleoni, oxbridge-i, humboldti modellek vagy az Etzkowitz-féle tőketermelési megközelítés is, amelyek mindegyike a fennálló gazdasági-politikai berendezkedésnek rendeli alá az egyetemet, és egyben annak valamely jól megragadható tényezőjének termelését várja el az egyetemtől. Ezt a modellt tehát egyfajta instrumentális szemlélet hatja át.

Mi indokolja, hogy ebben a modellben az egyetemre egyfajta termelőegységként tekintsünk? Leginkább az, hogy az egyetemtől konkrét, jól megfogható, a társadalom számára hasznos és kézzelfogható termékeket várunk el. Az egyetemek működésének sikerességét a végzett hallgatók, az előállított publikációk és szabadalmak számában és minőségében ragadjuk meg. Mi indokolja a szövetkezeti jelleget? Az, hogy az egyetemek müködése egy szövetkezetre hasonlít: a szövetkezetben a tagok nem csak a termelést végzik, hanem közremüködnek a szövetkezet (az egyetem) irányításában. Ennek alapját az jelenti, hogy az oktatók alapvetően szakértők, speciális tudás birtokosai, amely nehezen függetleníthető tőlük. Ez garantálja az alkupozíciójuk egy bizonyos fokát. Az önirányítás mértéke persze széles skálán változhat, de az oktatók valamilyen beleszólása az intézmény működésébe azért jellemzi ezt a müködési formát.

\subsection{Az egyetem mint katalizátor}

Második metaforánk a katalizátoré. E metaforában az egyetem társadalmi szerepe nem elsősorban valamilyen hasznos erőforrás (elit, tudás, munkaerő, kultúra, szakértő, tőke) előállítása, hanem a különböző gazdasági, társadalmi és politikai szereplők értékteremtő folyamatainak, és különösen a közöttük lévő együttműködések, közös megértések 
elösegítése. A tudás expanziójával az egyetemek szakértői monopóliuma megszünik, hiszen egyre több nem egyetemi szervezet folytat kutatási és szakértői tevékenységet (vállalatok kutatási részlegei, tanácsadó cégek, think tank-ek, közvélemény-kutató cégek stb.) és az internet révén az érdeklődő laikus szereplők is könnyebben válhatnak egy-egy téma szakértőjévé (internetes oldalak, peer learning group-ok létrejöttének egyszerübbé válása). Így mind az egyetemek, mind az egyetemi oktatók szakértői szerepvállalási lehetősége zsugorodik.

A tudás generálása viszont nemcsak a tárgyi szakértelmen, hanem a különböző egyetemen belüli és kívüli szakértők, valamint a felhasználói csoportok összehangolásán is múlik. A katalizátori szerepben az egyetemek igaz szakértelme nem a tárgyi tudásban, hanem a szereplők között zajló tudáskonstruálási folyamat facilitálásában rejlik. Nem azt várjuk el tehát, hogy az egyetemek önállóan eredményt (terméket) tudjanak felmutatni, hanem azt, hogy az egyetemek tudásgeneráló hálózatok kelesztői, kovászai legyenek. Az egyetem a katalizátor szerepében nem törekszik a társadalmi intézményrendszer radikális átalakítására, de mivel a tudásgeneráló hálózat bármilyen problémára irányulhat, ezért az egyetemek müködése kiterjedhet olyan szereplők és hálózatok támogatására is, amelyek ilyen célokkal müködnek.

A katalizátorszerephez olyan partnerekre van szükség, akik hajlandók együttmüködni másokkal, nyitottak a felvetésekre, kritikákra. Az egyetem az oktatás keretén belül tehát nem elsődlegesen szakértői tudást akar átadni, hanem a társas együttműködéshez szükséges kompetenciákat akarja fejleszteni: a nyitottságra, a párbeszédre és együttmüködésre való hajlamot, a tanulási vágyat, a reflexiós, kritikai és tanulási képességeket, a konstruktív visszajelzés képességének fejlesztését. A cél a reflektív szakemberek (reflective practitioner) képzése, és ez sokkal inkább a soft kompetenciák fejlesztésével, mint a tárgyi tudás átadásával történik. Ezért ez a szemlélet jól rokonítható azokkal a felsőoktatási missziókkal, amelyek az emberek kibontakozását, személyes fejlődését helyezik a középpontba.

A kutatás és a szolgáltatási folyamat összemosódik a katalizátoregyetemeknél, mert ezek az intézmények többnyire az úgynevezett Mód 2 tudástermelési folyamatokban vesznek részt. ${ }^{18}$ Ezek jellemzője, hogy a kutatási probléma nem egy tudományterület belső logikájából, igazságkereséséből fakad, hanem külső, praktikus igények által generált. További jellemző, hogy a kutatás kollaboratív folyamat, amelyekbe a megrendelő és más érintettek is kezdettől fogva aktívan bevonódnak. A résztvevő szereplők szakértelme, háttere ezért nagyon heterogén (szemben egy „hagyományos”, Mód 1-ben zajló kutatási folyamattal, amelyben egy szakterület kutatói vesznek részt).

Példaként gondoljuk egy olyan folyamatra, amelyben egy város önkormányzata szeretne egy köztér számára új funkciót találni. A folyamatba bekapcsolódó egyetem valamilyen elemzés vagy felmérés alapján tehet maga is javaslatot a kívánatos funkcióra (ez a szakértői tudás), de olyan folyamatot is létrehozhat, amelyben a tér funkciójának kitalálásába

18 Lásd Michael Gibbons (szerk.): The New Production of Knowledge. The Dynamics of Science and Research in Contemporary Societies. London, Sage Publications, 1994. 
és megvalósításába bevonják a helyi lakókat és más érintetteket (ez a folyamatfókusz, a Mód 2 tudástermelési folyamat). Egy ilyen folyamatban az egyetem sikerességét az határozza meg, hogy mennyire képes egyfajta karmesteri, katalizáló szerepben működni. Képes-e a közös problémamegoldási folyamatokat kialakítani és koordinálni, a releváns érintetteket megszólítani, bevonni, közöttük mediálni? Képes-e párbeszédet generálni, annak olyan kereteit kitalálni, amelyben az érintettek dialógust folytatnak egymással és közös álláspontra jutnak?

A kutatás tárgyának ismerete hasznos tudás a folyamatban, de nem nélkülözhetetlen, ez akár kívülről is bevonható. Ami viszont feltétlenül szükséges, az az együttműködési és bevonási folyamatok kialakításának módszertani ismerete. A részt vevő egyetemi oktatók szerepe nem a szakértői tanácsadás, hanem inkább egyfajta folyamat-tanácsadás. Ezt a módszertani szakértelmet olyan megközelítések alkalmazása fémjelzi, mint a co-creation, a co-production, az akciókutatás vagy a design thinking.

Vegyük észre, hogy a Mód 2 tudástermelési folyamat eredménye nem feltétlenül egy hagyományos (általánosítható törvényszerüségeket leíró tudást tartalmazó) publikáció, hanem egy lokálisan jól használható, beváló ismeret. A katalizátoregyetemek teljesítménye azért sem ragadható meg jól publikációkban, mert ilyenek vagy nem keletkeznek a folyamatban, vagy más szereplőknél keletkeznek. A siker fokmérője ezért nem az „impact factor”, hanem az „impact”: az, hogy a közös kutatási folyamatban megszülető megoldás müködik-e, elfogadják-e azt az érintettek. A fenti példában az új funkciót kapó közteret használják-e majd az érintettek.

A termelöszövetkezeti modellben látott instrumentális egyetemfelfogás helyett tehát ez a modell az egyetem társadalmi szintü társas konstrukciós folyamatokban betöltött szerepét hangsúlyozza. Ahogy Delanty fogalmaz:

„az egyetem nem tudja felvilágosítani a társadalmat, de keretet adhat a szakértői és laikus kultúra közötti közbeszédnek [...] A társas konstruktivista megközelítés elösegíti az egyetem új identitását, amely azon alapul, hogy képes reflexív módon bővíteni a társadalom diszkurzív képességét", 19

azaz képes a társadalom különböző szereplői közötti párbeszédet elősegíteni.

\subsection{Az egyetem mint világítótorony}

Az egyetem harmadik társadalmi szerepének metaforája a világítótorony. Ahogyan azt korábban már megfogalmaztam, az egyetem nemcsak erősítheti a fennálló gazdasági, társadalmi és politikai berendezkedést, hanem annak alternatíváit is megfogalmazhatja, sőt aktív szerepet is vállal az uralkodó intézmények radikális átalakítási kísérleteiben. Bár

19 Gerard Delanty: The University in the Knowledge Society. Organization, 8. (2001), 2. 151. 
az aktivizmus mértéke az egyes intézmények esetében változhat, az alternatívák megfogalmazása jellemzően valamilyen tudatos értékválasztás alapján történik (igazságosság, egyenlőség, demokrácia stb.), amely helyet kaphat akár az egyetem missziójában is. A világítótorony egyetem ideologikus és aktivista. Ez nem azt jelenti, hogy a többi egyetemfelfogás mögött nincsen ideológia, de ez nem feltétlenül vállalt vagy tudatos - szemben a világítótorony egyetemmel.

Ez a felfogás gyakran kiterjed magának az egyetemnek a müködésére is, hiszen az egyetem csak úgy tudja hitelesen képviselni az általa hirdetett elveket, ha azokat maga is megjeleníti. Például Morten és Greenwood a Creating a New Public University and Reviving Democracy címü könyvükben a szociáldemokrata eszmék jegyében gondolják újra az egyetemek szerepét. Így fogalmaznak:

„[A] demokrácia létfontosságú része az állami egyetemek szervezetének és az ott folyó oktatási, kutatási és szolgáltatási tevékenységeknek. Az alternatíva - sokak hierarchikus és önkényuralmi irányítása kevesek által - az, ami ma uralkodik. Ennek ellenére elismerjük, hogy az állami egyetemek világában nagyon kevés kulcsszereplő ért egyet abban, hogy a szociáldemokrata értékeken alapuló részvételi demokrácia az állami egyetemek alapvető jellemzője. Inkább a döntéshozók és a fö felsőoktatási hivatalnokok fogalmaznak meg valamilyen demokratikus és gazdasági küldetést az állami egyetemek számára a PR-kampányokban, hogy aztán költségvetés-csökkentéseket, valamint kényszerítő értékelési és rangsorolási rendszereket zúdítsanak az intézményekre. Tényleges viselkedésük világossá teszi, hogy a demokratikus retorika nem kötődik az erőforrások elosztásához vagy a vezetők valódi céljaihoz. [...] A globális elit pénzügyi és politikai birodalma feletti részvételi demokratikus ellenőrzés megszerzése félelmetes feladat." ${ }^{20}$

A világítótoronyként működő egyetemen az oktatás és kutatás nem öncélú, nem a diszciplína előremozdítása érdekében történik, hanem a társadalmi változások elérése érdekében.

$\mathrm{Az}$ egyetem a kutatás keretében rámutat a jelenlegi társadalmi, gazdasági és politikai rendszer működésének előfeltevéseire, ellentmondásaira és diszfunkcióira (például a vagyon és politikai egyenlőség kapcsolata), és hozzájárul az alternatív szerveződési módok konzisztens rendszereinek megfogalmazásához. Mindezzel előtérbe tolja és napirenden tartja azokat az értékeket, amelyek a fennálló berendezkedésben háttérbe szorulnak. Ezzel reflexiót és diskurzust kényszerít ki, ami az átalakulási folyamat első lépése. A kutatás tehát nemcsak leleplez, hanem kivezető uta(ka)t is mutat, és ebben az egyetem aktív kezdeményező szerepet játszik még akkor is, ha a megvalósításban már ugyanez csekélyebb. A világítótorony egyetem lényegében a kétkedés, a berendezkedés előfeltevéseire való rákérdezés és az alternatívakeresés intézményesített formája.

20 Morten Levin - Davydd J. Greenwood: Creating a New Public University and Reviving Democracy: Action Research in Higher Education. Berghahn Books, 2016. 3-5. 
Az oktatás révén az egyetem képes az (érték)tudatosságot, (társadalom)kritikai képességet, értékracionális attitüdöt közvetíteni. Az oktatás célja, hogy olyan egyének kerüljenek ki az egyetem falai közül, akik képviselik ezeket az értékeket, legyen szó egy igazságosabb vagy egyenlőbb társadalomról, a nők egyenjogúságáról vagy egy zöldebb, élhetőbb gazdaság alapjainak lerakásáról.

A társadalmi egyenlőség eszméjéhez szorosan kötődő megközelítés például a kritikai pedagógiai, amely „biztosítja az eszközöket annak megértéséhez, hogy a társadalmi intézmények milyen szerepet játszanak a társadalmi egyenlötlenségek és igazságtalanságok átörökítésében - ezt a szerepet a föáramú liberális elemzések érintetlenül hagyják” ${ }^{21}$ A kritikai pedagógiát „hagyományosan a marginalizált közösségeknél alkalmazták, hogy elérjék azt, amit Freire (1996) »tudatra ébredésnek« nevezett, ami egy eszköz arra, hogy a csoportok bevonják az uralkodó hatalmi struktúrákkal szembeni ellenállási stratégiákba”. ${ }^{22}$

Az egyetem harmadik missziós tevékenysége szorosan kötődik a képviselt világképhez: olyan tevékenységekben vesz részt, amely kapcsolódik (de legalábbis nem mond ellent) a transzformatív szemléletnek. Ez az a tér, ahol az egyetem aktivizmusa kibontakozhat.

A korábban ismertetett felsőoktatási társadalmi szerepek közül a világítótorony azokra rezonál, amelyek például az egyetem feladatául a társadalmak demokratikus müködésének erősítését vagy a társadalmi egyenlőtlenségek csökkentését állítják. Láttuk azonban Morten és Greenwood kritikáját is, amely szerint az ilyen kitételek sokszor csak legitimáló, retorikai szerepet játszanak.

\subsection{Az egyetem mint görbe tükör}

Az egyetem társadalmi szerepének negyedik modellje a görbe tükör, ahol az egyetem karikatúraszerűen ábrázolja a vizsgált jelenségeket: a társadalom működését éppúgy, mint a saját szerepét. Míg az előző három modell müködését valamilyen célirányosság jellemzi, addig a görbe tükör lényege a kritika és a kísérletezés.

A szabad kísérletezés annak lehetősége, hogy olyan témákat, ötleteket is megvalósítsunk (az oktatásban vagy kutatásban), amelyek meghökkentők, meglepők vagy provokatívak, és amelyek egy mainstream kutatási rezsimben talán nem is jutnának a legtöbb kutató eszébe, vagy nem is nyernének támogatást. Ide lehet sorolni például az Ignobel-díj keretében díjazott kutatások egy részét.

A kísérletezés része a kritika szabad gyakorlása is. A görbe tükör lényeges vonása, hogy az ábrázolt jelenség egy-egy meghatározó vonását emeli ki játékosan, akár egy karikatúra. Ezzel elgondolkodtatja a nézőt és bevonja a játékba anélkül, hogy bármilyen megoldást akarna sugallni. A következtetések levonását mindig a nézőre hagyja, a világítótoronnyal

\footnotetext{
${ }^{21}$ Charlie Cooper: Critical Pedagogy in Higher Education. In Charlie Cooper - S. Gormally - Hughes G. (szerk.): Socially Just, Radical Alternatives for Education and Youth Work Practice. London, Palgrave Macmillan, 2015. 46.

22 Cooper (2015): i. m. 51.
} 
ellentétben nem akarja azt szájba rágni. Pusztán rámutat egy-egy ellentmondásra, furcsa müködésmódra. A görbe tükörként müködő egyetem pontosan ezt teszi: provokál, meghökkent, megnevettet és játékra hív - ennek során pedig elgondolkodtat, reflexióra késztet. Az egyetem egyfajta posztmodern intézményként, szabad alkotó térként működik, amely sokféle művészi és kritikai irányzatnak ad teret, helyet, és sokféle, széttartó gondolkodásmódot is támogat. ${ }^{23}$

Az egyetem görbe tükröt nemcsak másnak, hanem saját magának is tart. Példaként hadd említsem meg a Journal of Universal Rejection ${ }^{24}$ címü „lapot”, amely egy tudományos folyóirat minden formális jegyével rendelkezik, de minden beérkező kéziratot elutasít. Ennek előnyei közé tartozik, hogy a beküldőnek nem kell idegeskednie az eredmény miatt, elmondhatja magáról, hogy az elutasítási arány alapján a világ legnagyobb presztízsü lapjába is küldött cikket, a beküldő minden jogot megtarthat, sőt a kéziratot párhuzamosan más lapokba is leadhatja. De hasonló példának tekinthetjük az egyetemi élet sajátosságait feldolgozó The Professors nevü zenekar számait, ${ }^{25}$ vagy a tudomány működését karikírozó olyan müveket, mint például Sigfried Bär írásai ${ }^{26}$ vagy a Dr. Ezésez Géza Karrierje, ${ }^{27}$ a phdcomics.com képregényei, esetleg Alan Sokal kezdeti tréfája (1996). ${ }^{28}$

A kritikára és kísérletezésre bátorító egyetemen az oktatás az érzékenység és az (ön)kritikai képességet erősítésére irányul, és teret enged a kreativitásnak, a nyelvi játékoknak és a (művészi) önkifejezésnek. A feladatok és a feladatok értékelési kritériumai meghökkentők.

A kutatás esetenként öncélúnak tünik (lásd Ignobel-díj), a harmadik misszióban pedig az egyetem inkább közös alkotó térként jelenik meg, ahol sokféle egyéni projekt követhető. Az egyetemi oktatók öntörvényü szabadgondolkodók, entellektüelek.

A görbe tükör talán leginkább az egyéni fejlődést középpontba helyező társadalmi szereppel mutat rokon vonásokat. Míg azonban az oxbridge-i modellben ez célirányosan, gyakran mester-tanítvány viszonyrendszerben valósult meg, addig a görbe tükörnél nehezen elképzelhetők a hierarchizált viszonyok és a valamilyen célnak (például társadalmi elit képzésének) való alárendelés is.

23 Ilyesmi jelenik meg a Felvéve (Accepted) címü 2006-os vígjátékban is: www.imdb.com/title/tt0384793/

24 Lásd: www.universalrejection.org/

25 Olyan számokat játszanak, mint például a „The untenured blues” vagy a „Peer review”. Lásd: www.theprofessors. net/

26 Sigfried Bär: Professzorok és alattvalók. A tudományos kutatás diszkrét bája. Budapest, Akadémiai Kiadó, 2003; Sigfried Bär: Az egyetemek lényege a professzorrá válásnak és a professzorok érzelmi életének tükrében. Budapest, Akadémiai Kiadó, 2005.

27 Dévényi Tibor: Dr. Ezésez Géza karrierje. Avagy tudósok és rágcsálók. Budapest, Gondolat, 1975.

28 Alan D. Sokal: Transgressing the Boundaries: Towards a Transformative Hermeneutics of Quantum Gravity. Social Text, (1996), 46-47. 217-252. 


\section{AZ EGYETEM MINT AZ ELLENTMONDÁSOK MEGTESTESÍTŐJE}

Az imént bemutatott négy modell főbb jellemzőit az alábbi táblázat foglalja össze:

1. táblázat • Az egyetem társadalmi szerepeinek modelljei (Forrás: a szerzö szerkesztése)

\begin{tabular}{|c|c|c|c|c|}
\hline & \begin{tabular}{|l|}
$\begin{array}{l}\text { Termelö- } \\
\text { szövetkezet }\end{array}$ \\
\end{tabular} & Katalizátor & Világítótorony & Görbe tükör \\
\hline $\begin{array}{l}\text { Folyamat-/ } \\
\text { Eredményfókusz }\end{array}$ & $\begin{array}{l}\text { Az egyetem } \\
\text { erőforrásokat } \\
\text { "termel” } \\
\text { (tőke, tudás, } \\
\text { munkaerő stb.) }\end{array}$ & $\begin{array}{l}\text { Az egyetem } \\
\text { együttmüködési } \\
\text { folyamatokat } \\
\text { katalizál }\end{array}$ & $\begin{array}{l}\text { Az egyetem } \\
\text { eröforrásokat } \\
\text { „termel” } \\
\text { (kritikai } \\
\text { alternatívák) } \\
\end{array}$ & $\begin{array}{l}\text { Az egyetem } \\
\text { megkérdőjelezési } \\
\text { folyamatokat } \\
\text { katalizál }\end{array}$ \\
\hline $\begin{array}{l}\text { Konszenzus-/ } \\
\text { Disszenzus fókusz }\end{array}$ & $\begin{array}{l}\text { Az uralkodó } \\
\text { társadalmi } \\
\text { berendezkedés } \\
\text { megerősítésére } \\
\text { törekszik }\end{array}$ & $\begin{array}{l}\text { Az uralkodó } \\
\text { társadalmi } \\
\text { berendezkedés } \\
\text { megerősítésére } \\
\text { törekszik }\end{array}$ & $\begin{array}{l}\text { Az uralkodó } \\
\text { társadalmi } \\
\text { berendezkedés } \\
\text { megváltoztatására } \\
\text { törekszik } \\
\end{array}$ & $\begin{array}{l}\text { Az uralkodó } \\
\text { társadalmi } \\
\text { berendezkedés } \\
\text { megkérdőjelezésére } \\
\text { törekszik }\end{array}$ \\
\hline $\begin{array}{l}\text { Fö társadalmi } \\
\text { szerep(ek) }\end{array}$ & \begin{tabular}{|l} 
Kontroll \\
és stabilitás \\
Az uralkodó \\
intézmények \\
fenntartása \\
a szükséges \\
erőforrások \\
elóállításával
\end{tabular} & $\begin{array}{l}\text { Kooperáció } \\
\text { és párbeszéd } \\
\text { A társadalmi } \\
\text { szereplők közötti } \\
\text { kooperáció } \\
\text { és párbeszéd } \\
\text { facilitálása, } \\
\text { strukturált } \\
\text { diszkurzív tér } \\
\text { a társadalom } \\
\text { számára }\end{array}$ & $\begin{array}{l}\text { Leleplezés } \\
\text { és változás } \\
\text { Uralkodó } \\
\text { intézmények } \\
\text { megkérdőjelezése, } \\
\text { alternatívák állítása } \\
\text { és a változásért } \\
\text { folytatott küzdelem }\end{array}$ & $\begin{array}{l}\text { Kísérletezés } \\
\text { és kritika: } \\
\text { Az uralkodó } \\
\text { intézmények } \\
\text { (beleértve } \\
\text { az egyetemet) } \\
\text { kifigurázása, hogy } \\
\text { a hallgatóságot } \\
\text { gondolkodásra } \\
\text { serkentse }\end{array}$ \\
\hline Oktatás & $\begin{array}{l}\text { Hatékony } \\
\text { munkaerő képzése }\end{array}$ & $\begin{array}{l}\text { Az együttmüködé- } \\
\text { sekben részt venni } \\
\text { képes reflektív hoz- } \\
\text { záértő szereplők } \\
\text { képzése } \\
\end{array}$ & $\begin{array}{l}\text { Transzformatív, } \\
\text { emancipált } \\
\text { és megvilágosodott } \\
\text { aktivisták képzése }\end{array}$ & \begin{tabular}{|l|} 
Szabad, kreatív, \\
érzékeny, önkifejezö \\
diákok képzése
\end{tabular} \\
\hline Kutatás & $\begin{array}{l}\text { Új termelö } \\
\text { és kontroll- } \\
\text { technológiák, } \\
\text { a rendszer } \\
\text { legitimitását erősítő } \\
\text { ismeretek } \\
\end{array}$ & $\begin{array}{l}\text { Co-creation } \\
\text { folyamatok } \\
\text { facilitálása, Mód } \\
2 \text { tudástermelés }\end{array}$ & $\begin{array}{l}\text { Ellentmondások } \\
\text { leleplezése } \\
\text { és kritikája, } \\
\text { az alternatívák } \\
\text { megalapozása }\end{array}$ & $\begin{array}{l}\text { Konvenciók } \\
\text { elhagyása, } \\
\text { ellentmondások } \\
\text { feltárása, ábrázolása }\end{array}$ \\
\hline Szolgáltatás & $\begin{array}{l}\text { Növekedés- } \\
\text { és hatékonyság- } \\
\text { fókuszú } \\
\text { szolgáltatások }\end{array}$ & $\begin{array}{l}\text { Co-creation } \\
\text { folyamatok } \\
\text { facilitálása, Mód } \\
2 \text { tudástermelés } \\
\end{array}$ & $\begin{array}{l}\text { Missziós tevé- } \\
\text { kenység - össz- } \\
\text { hangban a vállalt } \\
\text { értékekkel } \\
\end{array}$ & $\begin{array}{l}\text { Önkiteljesítés } \\
\text { és önkifejezés } \\
\text { számára teret adni }\end{array}$ \\
\hline Oktatói önkép & Szakértők & Facilitátorok & Forradalmárok & Entellektüelek \\
\hline
\end{tabular}

Az egyetemek társadalmi szerepével kapcsolatban bemutatott fenti rendszerezés kibővíti a szerepekkel kapcsolatos látóterünket, és válaszokat kínál a 20. században elbizonytalanodó egyetem számára. Ez elbizonytalanodás - monopólium- és autoritásvesztés, a nemzetállamokhoz füződő kapcsolatok gyengülése - ellenszereként kínálja a katalizátori szerepet, az egyetem azon képességét, hogy kontrollált és strukturált teret biztosít a társadalmi 
diskurzusoknak. De kitörési pont lehet az is, ha az egyetem a látszólag értéksemleges szakértői tudásra épülő modell (termelőszövetkezet) helyett elköteleződik valamilyen szélesebb körben elfogadott értékvilág mellett. Ezek olyan irányok, amelyek a hagyományos szerepértelmezések logikájába nem könnyen férnek bele.

A rendszerezés élesen veti fel azt a kérdést is, hogy melyik modellt érdemes választani. Vagy inkább azt, hogy kell-e modellt választani? Nem lehetséges, hogy az egyetemeknek (de legalábbis a felsőoktatási rendszernek) egyszerre kell megfelelniük mind a négy társadalmi szerepnek? Egyszerre kell a fennálló társadalmi berendezkedést kiszolgálniuk és a radikális átalakulásukat elősegíteniük; egyszerre kell ennek megfelelő „termékeket” előállítaniuk és mások működését katalizálniuk; egyszerre kell magukat komolyan venniük és kinevetniük?

Hogyan lenne ez lehetséges? Például olyan módon, ha az egyetem tudathasadásos intézménnyé („skizofrénné”) válik. Ennek szervezeti megfelelője az úgynevezett elválasztás (decoupling) és a laza kapcsolódás (loose coupling) stratégiája. Az előbbi esetben a szervezet retorikailag felvállalja egy adott elvárás teljesítését, de a tényleges gyakorlata ettől eltér (erre láttunk korábban példát a demokratikus elvek érvényesítése kapcsán). A loose coupling ${ }^{29}$ lényege pedig egy olyan laza struktúra alkalmazása, amely képessé teszi az egyetemet arra, hogy az egyik része más társadalmi célok mentén müködjön, mint a másik része. Ennek a tudathasadásos állapotnak a fenntarthatósága azon múlik, hogy a különböző részek mennyire képesek elfogadni egymást annak ellenére, hogy az egyetem társadalmi feladatáról mást gondolnak. A standardizált mérési és értékelési rendszerek, az erőteljes külső elszámoltatások kiélezik ezeket a viszonyokat, mert épp a kapcsolódás lazaságát szüntetik meg. Jól mutatja ezt például egy brit egyetem esete, ahol az oktatók egy csoportja megpróbált kritikai (azaz világítótorony) alapállású üzleti iskolát működtetni, ám végül az egyetem részben pénzügyi nyomások hatására átalakította azt egy mainstream alapállású (termelőszövetkezeti jellegü) üzleti iskolává. ${ }^{30}$

Clark Kerr az egyetem ellentmondásos természetét felismerve az universitas helyett a multiversitas kifejezést használta, amelyet így írt le:

„A multiversitas ellentmondásos intézmény. Ez nem egy közösség, hanem több [...] Határai homályosak [...] Intézményként messze a múltba és a jövőbe tekint, és gyakran ellentmond a jelennek. Szinte rabszolgaként szolgálja a társadalmat - azt a társadalmat, amelyet kritizál is, néha könyörtelenül. Az esélyegyenlőség híveként maga is osztálytársadalom. A közösségnek, mint a mesterek és a diákok középkori közösségeinek, közös érdekekkel kell rendelkeznie. A multiversitasban ezek meglehetősen változatosak, sőt ellentmondásosak. Egy közösségnek lelke, egyetlen éltető elve kell, hogy legyen;

29 Karl E. Weick: Educational Organizations as Loosely Coupled Systems. Administrative Science Quarterly, 21, (1976), 2. 1-19.

30 Martin Parker: The Critical Business School and the University: A Case Study of Resistance and Co-optation. Critical Sociology, 47. (2020), 7-8. 1111-1124. 
a multiversitasnak több is van - némelyikük egészen jó, bár sok vita folyik arról, hogy melyik lélek érdemel igazán üdvösséget.”31

Kavanagh úgy véli, hogy az egyetem lényegéhez tartozik a belső ellentmondásosság. Cikkében az egyetemet az udvari bolond metaforáján keresztül értelmezi, aki fontos szerepet tölt be az uralkodói udvarban. Időnként az uralkodó nevében jár el, és a maga módján teszi helyre az uralkodó elé járulókat, erősítve ezzel az uralkodó tekintélyét („termelőszövetkezet"). A bolond ugyanakkor az a személy is, aki a legkisebb kockázattal mondhatja mások előtt az uralkodó szemébe az igazságot, vagy mutathat rá annak hibáira („világítótorony”). Az udvari bolond feladata az is, hogy a közönséget szórakoztassa és jókedvre derítse, és olyan tréfákat, játékokat találjon ki, amelyek újféle dinamikákat visznek a közösségbe („katalizátor”). És időnként az udvari bolond magát is kigúnyolja, vagy olyan bölcsességeket fogalmaz meg, amelyek az adott időben és térben nehezen értelmezhetők, ám később mégis értelmet nyernek („görbe tükör”). Az egyetemek pontosan így egyensúlyoznak a mindenkori uralkodó intézményekkel (például a piaccal, az állammal, az egyházzal, az uralkodóval) szemben: szolgálják is, de az igazságot is a szemébe mondják, és újra és újra kikacsintanak más potenciális uralkodó intézmények felé is. ${ }^{32}$

$\mathrm{Az}$ egyetemek az ellentmondások megtestesítői. Az egyetemnek - ahogy Kavanagh megfogalmazta - „élnie kell intézményesítő és az intézményeket lebontó szerepével. Az Uralkodó(k)tól függő, lojális alattvalónak kell lennie, de ugyanakkor a partnereit sűrün váltogató szélhámosnak is. Gondoskodónak kell lennie, és mégis rettenthetetlenül kritikusnak. Központinak kell lennie, ugyanakkor jelentéktelennek. Támogatnia kell a rációt, ugyanakkor mindig meg kell ünnepelnie és el kell ismernie, hogy a bolondság alapvető. Röviden, az egyetemnek az oximoron intézményi megnyilvánulásának kell lennie, emlékezve arra, hogy ez a szó a görögből, az oxumorone-ból származik, ami azt jelenti, hogy »kifejezetten bolond «". ${ }^{33}$

\footnotetext{
Clark Kerr: The Uses of the University. 5th edition, Harvard University Press, 2001. 14-15. Donncha Kavanagh: Institutional Heterogeneity and Change: The University as Fool. Organization, 16. (2009), 4. 575-595.

$33 \quad$ Kavanagh (2009): i. m. 591.
} 


\section{FELHASZNÁLT IRODALOM}

1. Bär, Sigfried: Professzorok és alattvalók. A tudományos kutatás diszkrét bája. Budapest, Akadémiai Kiadó, 2003.

2. Bär, Sigfried: Az egyetemek lényege a professzorrá válásnak és a professzorok érzelmi életének tükrében. Budapest, Akadémiai Kiadó, 2005.

3. Barnett, Ronald: University Knowledge in an Age of Supercomplexity. Higher Education, 40. (2020), 409-422. Online: https://doi.org/10.1023/A:1004159513741

4. Barnett, Ronald: The Idea of the University: Renewing the Great Tradition. In Pedro Nuno Teixeira - Jung-Cheol Shin (szerk.): Encyclopedia of International Higher Education Systems and Institutions. Dordrecht, Springer, 2020. 2642-2648. Online: https://doi.org/10.1007/978-94-017-9553-1_11-2

5. Bologna Process: London Communiqué Towards the European Higher Education Area: responding to challenges in a globalised world (2007. május 18.). Online: www.ehea. info/Upload/document/ministerial_declarations/2007_London_Communique_English_588697.pdf

6. Clark, Burton R.: Creating Entrepreneurial Universities. Organizational Pathways of Transformation. London, IAU Press \& Emerald, 1998.

7. Council of Europe: Recommendation of the Committee of Ministers to member states on the public responsibility for higher education and research CM/Rec(2007) 6 (2007. május 16.). Online: https://search.coe.int/cm/Pages/result_details.aspx?ObjectId=09000016 805d5dae

8. Cooper, Charlie: Critical Pedagogy in Higher Education. In Charlie Cooper S. Gormally - Hughes G. (szerk.): Socially Just, Radical Alternatives for Education and Youth Work Practice. London, Palgrave Macmillan, 2015. Online: https://doi. org/10.1057/9781137393593_3

9. Delanty, Gerard: The University in the Knowledge Society. Organization, 8. (2001), 2. 149-153. Online: https://doi.org/10.1177/1350508401082002

10. Dévényi Tibor: Dr. Ezésez Géza karrierje. Avagy tudósok és rágcsálók. Budapest, Gondolat, 1975.

11. EMMI: Fokozatváltás a felsőoktatásban. Budapest, Emberi Erőforrások Minisztériuma, 2015.

12. Etzkowitz, Henry: The entrepreneurial university: vision and metrics. Industry \& Higher Education, 30. (2016), 2. 83-97. Online: https://doi.org/10.5367/ihe.2016.0303

13. Gibbons, Michael (szerk.): The New Production of Knowledge. The Dynamics of Science and Research in Contemporary Societies. London, Sage Publications, 1994.

14. Hrubos Ildikó: Differenciálódás, diverzifikálódás és homogenizálódás a felsőoktatásban. Educatio, 11. (2002), 1-4. 96-106. Online: http://epa.oszk.hu/01500/01551/ 00019/pdf/46.pdf\#page $=2$

15. Kavanagh, Donncha: Institutional Heterogeneity and Change: The University as Fool. Organization, 16.(2009), 4.575-595. Online: https://doi.org/10.1177/1350508409104509

16. Kerr, Clark: The Uses of the University. $5^{\text {th }}$ edition, Harvard University Press, 2001. 
17. Kováts Gergely: Az egyetemek fejlödéstörténete - és ennek tanulságai. In Hrubos Ildikó - Luda Szilvia - Török Imre (szerk.): Intézményi menedzsment a felsőoktatásban 3. Budapest, FGSZE, 2013. 45-68.

18. Magna Charta Universitatum (1988). www.felvi.hu/felsooktatasimuhely/archivum/ kulfold/magna_charta_universitatum

19. Magyarország Kormánya: Széll Kálmán terv összefogás az adósság ellen (2011). Online: https://2010-2014.kormany.hu/download/4/d1/20000/Sz\%C3\%A911\%20K\%C3\% A1lm\%C3\%A1n\%20Terv.pdf

20. Martin, Ben R. - Henry Etzkowitz: The Origin and Evolution of the University Species. Journal for Science and Technology Studies (VEST), (2001), 13. 9-34. Online: http://sro.sussex.ac.uk/id/eprint/19557

21. Menezes, Isabel - Márcia Coelho - Jose P. Amorim: Social and Public Responsibility, Universities. In Pedro Nuno Teixeira - Jung-Cheol Shin (szerk.): Encyclopedia of International Higher Education Systems and Institutions. Dordrecht, Springer, 2020. 25402545. Online: https://doi.org/10.1007/978-94-017-9553-1_361-1

22. Levin, Morten - Davydd J. Greenwood: Creating a New Public University and Reviving Democracy: Action Research in Higher Education. Berghahn Books, 2016. DOI: https:// doi.org/10.2307/j.ctvss40p6

23. Parker, Martin: The Critical Business School and the University: A Case Study of Resistance and Co-optation. Critical Sociology, 47. (2020), 7-8. 1111-1124. Online: https://doi.org/10.1177/0896920520950387

24. Readings, Bill: The University in Ruins. Cambridge (Ma.) and London, Harvard University Press, 1996.

25. Sokal, Alan D.: Transgressing the Boundaries: Towards a Transformative Hermeneutics of Quantum Gravity. Social Text, (1996), 46-47. 217-252. Online: https:/doi.org/ $10.2307 / 466856$

26. UNESCO: World Conference on Higher Education 2009. Final report. Paris, UNESCO. (2009).

27. Weick, Karl E.: Educational Organizations as Loosely Coupled Systems. Administrative Science Quarterly, 21, (1976), 2. 1-19. Online: https://doi.org/10.2307/2391875

28. Zgaga, Pavel: Higher Education and Citizenship: 'The Full Range of Purposes.' European Educational Research Journal, 8, (2009), 2. 175-188. Online: https://doi. org/10.2304/eerj.2009.8.2.175 
Kováts Gergely a Budapesti Corvinus Egyetem Vezetéstudományi Intézetének docense és a Nemzetközi Felsőoktatási Kutatások Központjának igazgatója. Mesterdiplomáit a Budapesti Közgazdaságtudományi és Államigazgatási Egyetemen, illetve a londoni Institute of Education (ma: University College London) intézményben szerezte. Doktori fokozatát a Budapesti Corvinus Egyetemen védte meg. 2006 és 2019 között a Budapesti Corvinus Egyetem minőségfejlesztéssel foglalkozó szervezeti egységeiben dolgozott, ahol elégedettségi felmérések, akkreditációs folyamatok, vezetői információs rendszerek és intézményi stratégia kidolgozásában és megvalósításában vett részt. Kutatóként fő érdeklődési területei a felsőoktatási intézmények kormányzása és menedzsmentje, továbbá a felsőoktatás-politika és finanszírozás, de tanít szervezetelméletet és közmenedzsmentet is. Több mint 100 angol és magyar nyelvű tudományos publikáció szerzője. 